\title{
Role of Ayurveda in the Management of Guillain-Barré Syndrome
}

\author{
Case Study
}

\section{Sadhana Misar Wajpeyi ${ }^{1^{*}}$}

1. Associate Professor, Department of Kayachikitsa, Mahatma Gandhi Ayurveda College Hospital \& Research Centre, Salod(H),Wardha

\begin{abstract}
Guillain-Barré syndrome (GBS) is a peripheral neuropathy with acute onset, and characterized by rapidly developing motor weakness. It is autoimmune in nature and triggered by a preceding infection. A 48 years old female patient was brought with complaints of paralysis of all the four limbs (quadriplegia), back pain and pain in the right lower limb since one month. She was previously treated in tertiary care hospital with IV Immunoglobulin and plasmapheresis but showed no improvement. So she admitted and treated in Mahatma Gandhi Ayurved College Hospital \& Research Centre, Salod (H) Wardha on 21.06.2018. In Ayurveda, there is no direct description of this disease but this condition can be correlated with Sarvanga vata (vata affecting all parts of the body), hence she was treated following principles of Vatavyadhi chikitsa which include A bhyanga (Oleation therapy), Swedana (Fomentation), Matrabasti (enema with medicated oil), Nasya (Nasal medicated oil administration) and various herbomineral formulations for 51 days. Along with this physiotherapy and Trans Electrical Nerve Stimulation was also applied. Significant results were observed in the form of improvement in the muscle power from zero to four for all the four limbs with improvement in her general condition as well as daily activities
\end{abstract}

Keywords: Abhyanga, Basti, GBS, Sarvanga vata, Shashtika shali pindasweda, Vatavyadhi.

\section{Introduction}

Guillain Barré syndrome (GBS) is an acute, frequently severe, and fulminant polyradiculoneuropathy that is autoimmune in nature. It occurs year-round at a rate of between 1 and 4 cases per 100,000 annually; in the United States, 5000-6000 cases occur per year. Males are at slightly higher risk for GBS than females. GBS manifests as a rapidly evolving are flexic motor paralysis with or without sensory disturbance. The usual pattern is an ascending paralysis that may be first noticed as rubbery legs. Weakness typically evolves over hours to a few days and is frequently accompanied by tingling dysesthesias in the extremities. The legs are usually more affected than the arms, and facial diparesis is present in $50 \%$ of affected individuals. Pain in the neck, shoulder, back or diffusely over the spine is also common in the early stages of GBS, occurring in $\sim 50 \%$ of patients. Approximately $70 \%$ of cases of GBS occur 1-3 weeks after an acute infectious process, usually respiratory or gastrointestinal (1).

Treatment of GBS according to Modern Medicine includes Intravenous Immunoglobulin and Plasma pheresis which both are expensive (2).Hence there is need of cost effective treatment, which improves the Quality of Life in the patients having no side effects.

In Ayurveda no such disease is described but on the basis of symptoms this condition can be correlated

*Corresponding Author:

Sadhana Misar Wajpeyi

Associate Professor, Department of Kayachikitsa,

Mahatma Gandhi Ayurveda College Hospital \&

Research centre, Salod(H), Wardha

Email id: sadhanamisar@gmail.com with Sarvanga vata that is vata affecting all parts of the body. It is described in snayugata dushta vata lakshana by Acharya Charak in Vatavyadhi chikitsa adhyaya. In Vatavyadhi predominance of vata dosha is present hence the principles of Vatavyadhi chikitsa can be used in treating this condition (3). It includes Snehana (oleation therapy), Swedana (fomentation), Shashtika shali pinda sweda (4). (sudation using a shashtika rice cooked in milk and Balakwath), Basti (Medicated enema), Nasya (administration of medicated oil in nostrils) and use of vatahar formulations.

\section{Case Report}

A 48 years old female patient (OPD No1806210096-21/06/18) was brought with complaints of paralysis of all the four limbs (quadriplegia). She also had complaints of back pain and pain in the right lower limb since one month. She had increase frequency of micturition. She was a known case of hypertension and was taking treatment for the same regularly since 3 years. She was also taking medicines for Diabetes mellitus since one month.

\section{Past history}

Patient was alright before one month. She had fever and loose motion and took medicines for the same from family physician for 3-4 days. Later on she started feeling weakness in both lower limbs. The weakness progressed into both upper limbs as well. The intensity of the weakness gradually increased. After 2-3 days she seeked advice of a medical specialist and hence went a tertiary care unit. Meanwhile she also developed difficulty in breathing. There she was investigated for Electromyelogram (EMG), Nerve Conduction Velocity (NCV) and MRI. She also underwent blood and other 
routine investigations and then was diagnosed as suffering from Guillain Barre Syndrome on 25/05/2018.

She was given IV Immunoglobulin infusion, Injection Lupinox 0.4ml OD S/C, Injection Dynapar 1cc TDS IV, Injection Pan 40mg, Syp.Duphalac 30ml SOS and IV Fluids. Patient was shifted to another tertiary care hospital. There she was treated with IV Immunoglobulin, Inj. Lupinox, Inj. Eldervit, Inj. Dynapar, Inj. Tramadol, Inj. Pan, Tab. Atorva, Tab.Gabantip AT, Tab.Benformet plus, Tab. Glycomet GP 2, Tab.Lenol ER, Syp. Duphalac, IV Fluids meanwhile she was given physiotherapy and Trans Elecrical Nerve Stimulation. But there was no improvement. Then 8 cycles of plasmapheresis were given. With this there was improved in the respiratory functions but no improvement in quadriplegia. She was advised physiotherapy and Trans Electrical Nerve Stimulation. Then she came to Kayachikitsa OPD of Mahatma Gandhi Ayurved College Hospital \& Research Centre, Salod (H) Wardha on 21.06.2018.

\section{Examination of patient on admission- Ashtavidhapariksha}

The patient's pulse was vatakapha predominant and tongue was saam (coated). She had sthula akruti (obese) having weight $78 \mathrm{~kg}$. She was catheterized with No.16 Foley's catheter.

\section{General examination}

The general condition of patient was moderate, she was afebrile with pulse rate 110/min, Blood pressure $130 / 80 \mathrm{~mm} \mathrm{Hg}$ and respiratory rate $18 / \mathrm{min}$. Her chest movements were normal and equal on both sides.

\section{Systemic examination}

In the systemic examination, findings of respiratory and cardiovascular system were within normal limits. Abdomen was mildly distended, nontender and bowel sounds were present. Patient was conscious, well oriented with time and place and responding well to commands. Pupillary reaction to light was normal. Examination of cranial nerves was normal. Muscle atrophy was absent. Muscle fasciculations and irritability absent. Involuntary movements were absent. Muscle tone -All four limbs flaccid.

Table No.1: Showing Muscle power gradation: On admission

\begin{tabular}{|c|c|c|}
\hline & Right & Left \\
\hline Upper limb & $0 / 5$ & $0 / 5$ \\
\hline Lower limb & $0 / 5$ & $0 / 5$ \\
\hline
\end{tabular}

\section{Gradation of Muscle Power --The Following are the} Gradation of the Muscle Power (5)

0- Complete paralysis

1- A flicker of contraction only without any movement

2- Movements possible with gravity elimination

3- Movements possible against gravity but not against Resistance
4- Movements possible against gravity plus resistance but weaker than normal

5- Movements against gravity and full resistance ( Normal Power)

\section{Examination on admission-}

Table no.2- Hughes GBS Disability Scale (6)

\begin{tabular}{|l|l|}
\hline $\begin{array}{l}\text { Hughes GBS } \\
\text { Disability Scale }\end{array}$ & $4 / 6$ \\
\hline $\begin{array}{l}\text { Cranial nerve } \\
\text { examination }\end{array}$ & All cranial nerves intact \\
\hline $\begin{array}{l}\text { CN XI (Accessory } \\
\text { nerve) }\end{array}$ & $\begin{array}{l}\text { Shrugging of shoulders - } \\
\text { not possible with } \\
\text { resistance }\end{array}$ \\
\hline
\end{tabular}

Hughes functional grading scale for GBS Score Description

0 : Healthy

1: Minor symptoms or signs, able to run

2: Able to walk $5 \mathrm{~m}$ independently

3: Able to walk $5 \mathrm{~m}$ with a walker or support

4: Bed- or chair-bound

5: Requiring assisted ventilation

6: Death

\section{Reflexes}

- Visceral reflexes (micturition \&bowel) - Intact

- Superficial reflexes - Glabellar tap reflex -ve

- Abdominal reflex (both sides) -ve

- Babinski’s sign (B/L) -ve

\section{Deep tendon reflexes-}

- B/L Upper Limb: Biceps, triceps, radial jerks absent (areflexia)

- Lower Limbs: Knee \& ankle jerks - absent (areflexia)

- Clonus -absent

- Co-ordination - can't be elicited.

\section{Sensory nerves:}

- Tactile sensation, temperature sense- intact

- Tactile Discrimination, Position sense - Intact

- Vibration sense and Stereognosis - Intact.

\section{Investigations}

Routine investigations of blood, urine, liver function, renal functions, serum electrolytes, CPK were within normal limits. normal.

CT-Scan of brain and MRI lumbar spine was

Electromyogram and Nerve Conduction Velocity showed symmetrical sensory motor axonal polyradiculoneuropathy affecting both UL \& LL.

Impression: GB Syndrome.

\section{Treatment given}

- Bahya Snehana (External oleation)- Abhyanga with Ashwagandha bala taila in anuloma gati (downward) for 20min. 
- Nadisweda by Nirguṇdi (Vitex nigundo) and Dashamula siddha kwatha (decoction) for a period of 15 minutes.

- Shashtika shali pinda sweda-Bala mula (root of Sida cordifolia Linn.) and Ashwagandha (Withania somnifera Linn.) were taken in equal quantity each of $20 \mathrm{gm}$ and $500 \mathrm{ml}$ of milk was processed by boiling it to reduce the quantity to half. Then $50 \mathrm{~g}$ of Shashtika shali ( rice harvested in 60 days) was cooked in this milk to form the paste. Then pottali of this paste was formed and applied with gentle circular motions for $30 \mathrm{~min}$ in anuloma gati.

- Nasya with Ksheerabala taila 8 drops in each nostrils.

- Matrabasti 50ml (enema of medicated oil) of Ashwagandha taila (Withania somnifera Linn.) was given for 7 days.
- Brhatvatachitamani Rasa 60mg mixed with Guduchi (Tinospora cordifolia Linn.) churna 2gm and Ashwagandha Churna $2 \mathrm{gm}$ was given.

- Capsule Palsineuron 500mg three times a day.

- Physiotherapy.

- Trans electrical nerve stimulation once in a day.

- Patient was treated for a total of 51 days.

\section{Result and Observations}

Improvement in Symptoms Before and After Treatment was noted. Patient admitted on 21.06.2018. Above treatment was started and continued for 51 days. Patient was assessed weekly and improvement was noted as following.

Table no.3- Showing Improvement of patient after treatment

\begin{tabular}{|l|l|l|l|l|l|l|}
\hline SN & Date & Daily routine activities & \multicolumn{4}{l|}{ Muscle power grade } \\
\cline { 4 - 7 } & & & $\begin{array}{l}\text { Right } \\
\text { Upper } \\
\text { limb }\end{array}$ & $\begin{array}{l}\text { Left } \\
\text { Upper } \\
\text { limb }\end{array}$ & $\begin{array}{l}\text { Right } \\
\text { Lower } \\
\text { limb }\end{array}$ & $\begin{array}{l}\text { Left } \\
\text { lower } \\
\text { limb }\end{array}$ \\
\hline 1 & 21.06 .2018 & Patient unable to sit, stand and walk & $0 / 5$ & $0 / 5$ & $0 / 5$ & $0 / 5$ \\
\hline 2 & 28.06 .2018 & Patient unable to sit, stand and walk & $0 / 5$ & $0 / 5$ & $1 / 5$ & $0 / 5$ \\
\hline 3 & 05.07 .2018 & $\begin{array}{l}\text { Patient can sit with support for 15- } \\
\text { 20mins. }\end{array}$ & $1 / 5$ & $1 / 5$ & $1 / 5$ & $1 / 5$ \\
\hline 4 & 12.07 .2018 & $\begin{array}{l}\text { Patient can sit with support upto 30-45 } \\
\text { mins. }\end{array}$ & $2 / 5$ & $2 / 5$ & $2 / 5$ & $2 / 5$ \\
\hline 5 & 19.07 .2018 & Patient can sit without support. & $2 / 5$ & $2 / 5$ & $2 / 5$ & $2 / 5$ \\
\hline 6 & 26.07 .2018 & $\begin{array}{l}\text { Patient can stand with support for 15- } \\
\text { 20mins. }\end{array}$ & $3 / 5$ & $3 / 5$ & $3 / 5$ & $3 / 5$ \\
\hline 7 & 02.08 .2018 & Patient can stand without support. & $3 / 5$ & $3 / 5$ & $4 / 5$ & $3 / 5$ \\
\hline 8 & 09.08 .2018 & Patient can walk with support. & $4 / 5$ & $4 / 5$ & $4 / 5$ & $4 / 5$ \\
\hline
\end{tabular}

Table no. 4: Showing reflexes before and after treatment

\begin{tabular}{|c|c|c|}
\hline Reflexes & BT & AT \\
\hline Planter & Absent & Flexor \\
\hline Biceps & Absent & + \\
\hline Triceps & Absent & + \\
\hline Ankle & Absent & + \\
\hline Knee & Absent & \\
\hline
\end{tabular}

\section{Discussion}

GBS is an Autoimmune Disease. In modern medicine pathogenesis in the demyelinating forms of GBS, the basis for flaccid paralysis and sensory disturbance is conduction block. This finding, demonstrable electrophysiologically, implies that the axonal connections remain intact. Hence, recovery can take place rapidly as remyelination occurs. In severe cases of demyelinating GBS, secondary axonal degeneration usually occurs; its extent can be estimated electrophysiologically. More secondary axonal degeneration correlates with a slower rate of recovery and a greater degree of residual disability. When a severe primary axonal pattern is encountered electrophysiologically, the implication is that axons have degenerated and become disconnected from their targets, specifically the neuromuscular junctions, and must therefore regenerate for recovery to take place. In motor axonal cases in which recovery is rapid, the lesion is thought to be localized to preterminal motor branches, allowing regeneration and reinnervation to take place quickly. Alternatively, in mild cases, collateral sprouting and reinnervation from surviving motor axons near the neuromuscular junction may begin to reestablish physiologic continuity with muscle cells over a period of several months (7).

There is no direct reference of GBS in Ayurveda classics but according to its clinical features, and involvement of the doshas and dushyas it can be correlated with Sarvanga Vatvvyadhi. The 'Vaat' is described as "Vaa Gati Gandhanayoh" wherein 'Gati' represents 'Motor function and 'Gandhana' represents 
'Sensory function. Samprapti of this mainly involves predominance of Vaat Dosha, as entire Nervous System is under the Control of Vata it is mainly responsible for all movements in the body. Hence, correction of Vata is very important in treatment of GB syndrome. Hence this case of GB syndrome was treated by using Vatavyadhi chikitsa sutra. The main chikitsa of Vatavyadhi includes bahya Snehana, Swedana, Basti and Vatahar chikitsa using various herbomineral formulations (8).

For Abhyanga Ashwagandha bala taila was used. It alleviates vatadosha, it is pushtikara (strength promoter) and Jarahar (prevents aging). Considering the vitiation of vata dosha and dhatukshaya Vatahar and balya taila was selected and movements were performed in anuloma gati which reduces its chalaguna (property to move) causing inability to transmit nerve impulses (9).

Shashtika shali pinda Sweda helps in nourishment of muscles and in improvement of the movements. It is a type of Brimhana Sweda (nourishment) having Vatahara (vata alleviating) and Balya (Strength promoter) property. Its ingredients like milk and Shashtika Shali nourishes and gives strength to muscle tissues. Bala and Ashwagandha gives nourishment to nervous tissues. During application of taila the heat is generated which causes vasodialation, because of which the blood circulation improves causing removal of waste products. Improvement in blood circulation helps in nutrition of muscle tissues. It decreases stiffness of muscles and increases strength and flexibility of muscles which helps in improving movements(10). Skin i.e. Sparshanendriya is considered as the site of Vata. Hence Shashtika shali pinda sweda when applied directly on the skin lead to the correction of the deranged Vata, which helps in correction of the impaired functions (11). Shashtika shali pinda sweda (fomentation using Shashtikashali rice cooked in milk processed with Bala (Sida cordifolia Linn.) and Ashwagandha (Withania somnifera Linn.) was used. All ingredients of the pindasweda, ksheer (milk), Shashtika shali and Balamula have santarpana qualities (Antioxidantant and nourishing) and is indicated for balya (strenghthening), brimhana (nourishing) of dhatus with alleviation of vata. Shashtika shali helps in opening up of blocks in nerve conduction and facilitates remyelination of nerves which helps in transmitting nerve impulses $(12,13)$.

Basti (medicated enema) is an effective treatment for vata. It also brings about anulomana (Downward movement) of vata. Matrabasti is a type of abhyantar snehana which helps in pacifying Vatadosha. Ashwagandha taila matrabasti $50 \mathrm{ml}$ was given for 15 days. This route of administration of medication also facilitates its rapid absorption. Ashwagandha is balya, rasayana and gives strength to nerves Nasya is the route of administration of drugs through nose as it reaches to the brain and eliminates the morbid doshas responsible for producing the vyadhi (14).

Nasya is indicated in all Urdhvajatrugata vikara (diseases of upper part). Diseases of spinal cords and roots can be considered under Urdhvajatrugata vikara. Nasya can be given in neurological disorder in which muscle wasting and muscular weakness is present.
Ksheerabala taila is used in this case which rapidly get absorbed and causes bruhana and helps in alleviation of vatadosha in urdhvajatrugata part (15).

Brihatavatachintamani Rasa (prepared by Sri Dhootapaapeshwara Pvt. Ltd.), a Suvarnakalpa which contains Suvarna bhasma, Roupya bhasma, Abhrak bhasma, Praval bhasma, Mouktika bhasma, Louha bhasma, Rassindoor with bhavana of Ghrita Kumari (Aloe vera Tourn.ex Linn.) is an excellent Vatashamak, Balya and Rasayana. All ingredients of it are indicated as a stimulant, nervine, nootropic and rejuvenative action which improves the acuity of mind and indicated in the management of stroke. It is an excellent rejuvenative and anti-aging medicine (16).

$$
\text { Capsule Palsineuron contains }
$$

Mahavatavidhwansa, Samirpannaga, Ekangvir rasa, Khursani Ova (Hyoscyamus niger Linn.), Lajjalu (Mimosa pudica Linn.) manufactured by $S G$ Phyto Pharma Pvt. Ltd., Kolhapur. It manily works on neuromuscular disorders. Mahavatvidhwansa improves metabolic processes in CNS and PNS, activates neuromuscular communication, Sameerpannag improves tissue oxidation and regulates blood supply in affected areas, Ekangveer Ras promotes healing of damaged nerves and blood vessels, Sootshekhar Rasa provides nutritional support for faster healing of damaged tissues. Lajjalu has regenerative effect on neuro-lesions. Khurasani Owa checks neuro-irritation. Due to properties of these ingredients it is indicated in cases of neuro-muscular disorders of CNS and PNS, hemiplegia, general paralysis, facial paralysis, hand shoulder syndrome, convulsions, whole body stiffness, sciatica, nerve injury, neuralgia (nerve pain), cramps in calf, myalgia (muscle pain), Migraine and other neurodegenerative disorders $(17,18,19)$.

Guduchi (Tinospora cordifolia (Willd) Miers ex Hook. F. \& Thoms) and Ashwagandha (Withania somnifera Linn.) both have balya and Rasayana properties which helps in strengthening and promoting bulk of muscle tissue. It has immunomodulatary action, which helps in correcting immune dysfunction of the body and helps in reducing stress $(20,21)$ Physiotherapies like passive exercises, passive assisted exercises and resistive exercises were started when patient was in complete bedridden condition. Later on strengthening exercises for quadriceps, hamstrings, deltoid and biceps muscles along with calf muscle stretching exercises were given. After gaining muscle strength of lower limbs and when patient started to stand with support, co-ordination exercises, knee balancing and ankle balancing exercises started. Studies have shown that physical fitness can positively influence not only outcomes such as mobility and fatigue levels in GBS patients (GBSPs) but also mental functioning $(22,23)$. Along with this Electrical nerve stimulation for lower back, upper and lower limb was started which helps in reducing pain (24).

Significant results were observed in the form of improvement in the muscle power. The muscle power was zero in all four extremities at the time of admission which improved to four after treatment with improvement in general condition of patient. According 
to modern medicine, it takes several months to year in patients of GBS to achieve full functional recovery (25). In this patient recovery was seen in one and half months, which suggests the rapid recovery due to favorable effects of management of principles given in Ayurveda.

\section{Conclusion}

Guillain Barre syndrome can be compared with Sarvanga Vatavyadhi. From this case study it can be concluded that GB syndrome can be effectively treated with using Vatavyadhi chikitsa sutra like Abhyanga, Shashtika shali pinda sweda, Basti, Nasya and various herbomineral formulations like Brihatavatachintamani rasa, Ekangvir rasa, Guduchi and Ashwagandha. Physiotherapy and Trans Electrical Nerve Stimulation also have prime role in improving condition GB syndrome patient. All this treatment is cost effective and having minimum or no side effects and if given adjuvant to Modern medicine showed rapid improvement. This is a single case study so to prove effectiveness of chikitsa principles it should be conducted on large sample size for long duration of time.

\section{References}

1. Kasper, Fauci, Hauser, Longo Harrisons principles of internal medicine, vol.2, 19th edition, pg-2694

2. Kasper, Fauci, Hauser, Longo Harrisons principles of internal medicine, vol.2, 19th edition, pg-2697

3. Tripathi R. Charak Samhita of Charaka, Chikitsasthan, Vatvyadhi Chikitsa. Varanasi: Chaukhamba Sanskrit Series; 2009. p. 691

4. Mahadevan L, Srividya S, Jeyalakshmi B. Dr. L. Mahadevan's Guide to Ayurvedic Clinical Practise Neurology. Vol. 2. Kanyakumari, Tamil Nadu, India: Sarada Mahadeva Iyer Ayurvedic Educational and Charitable Trust Derisanamscope; 2011. p. 300-1.

5. Kundu AK, Bedside Clinics in Medicine, Part I, $7^{\text {th }}$ Edition,Jaypee Brothers Medical Publisher(P), Ltd.,New Delhi, pg.180

6. Hughes RA, Newsom-Davis JM, Perkin Gd, Pierce JM. Controlled trial prednisolone in acute polyneuropathy. Lancet. 1978;2:750-3.

7. Kasper, Fauci, Hauser, Longo Harrisons principle of internal medicine, vol.2, 19th edition, pg-2697

8. Tripathi Brahmananda, Charak samhita,Vol.2,Chikitsa sthana,Vatavyadhi chikita-28 pp 954

9. Kasture HS. Aayurvediya Panchkarmavidnyan of Haridas S Kasture, Sweda Vidnaniya. Nagpur: Baidyanath Aayurved Bhavan Publication; 7th ed. p. 168.

10. Nishteswar K, Sahasrayogam, Chowkhamba Sanskrit Series Office, print-2006, pg-117, pp-540.

11. Martin FH. fundamentals of anatomy and physiology chapter 5, 4th ed, New jarsy. prentice hall inc. simon \& Schuster; 1998.
12. Padhi M.M., Sharda Ota, Sharma M.M., Venkateshwarlu. B.; A Practical Handbook of Panchakarma Procedures; New Delhi. C.C.R.A.S.2010, Pg no 4547.

13. Vipin et. al. "A case study on the effect of shashtik shali pinda sweda and mahamasha taila nasya karma in the management of ekanga vata with mamsakshaya w.s.r. demyelination of nerve", World Journal of Pharmacy and Pharmaceutical Sciences Volume 6, Issue 10,2017,pp 1291-1296.

14. Amritha E Pady, Muralidhara, Shridhar, Byresh A. Management of Guillain Barre Syndrome Through Ayurveda-A Case Study. International Journal of Ayurveda and Pharma Research. 2016;4(12):36-40.

15. Agnivesha, Charaka Samhita, Vidyotini Hindi commentary by Kashinatha Shastri and Gorakha Natha Chaturvedi, Sidhi Sthana 2/22, Chaukhambha Bharati Academy, Varanasi, Reprint 2005, Pg. no. 986.

16. Mishra Sidhinandan., Govindas Sen. Bhaishajya Ratnavali. Chaukhamba Sanskrit Pratishthan Oriental Publishers \& Distributors, New Delhi, India Shloka No. 141. 1st ed.. 2013.

17. https://www.sgphyto.com/product/palsinuroncapsules/ [Date-11.11.2018 at 12.40am]

18. https://ayurmedinfo.com/2012/08/10/palsinuroncapsules-benefits-dosage-ingredients-side-effects/ [Date-11.11.2018,12.45am]

19. Philip Anand Kumar, B R K R Govt. Ayurvedic College and Hospital, Erragadda, Hyderabad, Clinical Study Report A Parallel two armed, randomized, open labelled, Phase III Clinical study comparing the Palsinuron Vs Mahavatvidhwans ras in the management of Migraine (Ardhava Bhedaka), July 2012

20. Singh SS, Pandey SC, Srivastav S. Chemical and medicinal properties of tinospora cordifolia. Indian J Pharmacol 2003; 35:83-91. 16.

21. Krishna KL, Bhatt J, Patel J. Guduchi (Tinospora cordifolia): Biological and medicinal properties, a review. Internet J Altern Med 2009; 6:10-5

22. Waghavkar S, Ganvir S Enhancement of Recovery with Physical Therapy Management in Patient of Rare Variety of Gullain Barre Syndrome: A Case Report. Physiother Rehabil 1: 107. (2016) doi:10.4172/2573-0312.1000107

23. Nicholas Simatos Arsenault, et.al.Influence of Exercise on Patients with Guillain-Barré Syndrome: A Systematic Review Physiother Can. Fall 2016; 68 (4): $367-376$

24. CarthyA. Mc, James \& Zigenfus, Robert. (1978). Transcutaneous Electrical Nerve Stimulation: An Adjunct in the Pain Management of Guillain-Barré Syndrome. Physical therapy. 58. 23-4. 10.1093/ $\mathrm{ptj} / 58.1 .23$.

25. Kasper, Fauci, Hauser, Longo Harrisons principles of internal medicine, vol.2, 19th edition, pg-2770 